\title{
Environmental accounting of tdb College Campus: a Step Towards Sustainability
}

\author{
Dr. Sarbendu Bikash Dhar \\ Assistant Professor, Department of Geography, Trivenidevi Bhalotia College, Raniganj, India
}

\begin{abstract}
The concept of "environmental sustainability" is a global matter of concern in these days. Any anthropogenic activity results in the loss or alteration of natural environment in the specific area concerned. Hence, attempts should be made to balance the developmental activities between humanised and natural landscape. For this, the ideas for achieving the sustainability may be implemented at local levels to get its result at global scaleUnlike industrial, commercial, residential or agricultural practices, an educational institution also has profound impact on its surrounding environment. In the present study, the campus area of Trivenidevi Bhalotia (TDB) College has been scrutinised in this purpose. For a holistic environmental approach of the study, both natural, as well as the socio-economic environmental components of the campus area have been analysed in the present study. A biodiversity accounting has been done to interpret the natural environmental condition of the college campus. TDB college campus, the area under study, is comprising of 30 bighas of land, of which almost 36 percent is open space. That consists of remarkable plant and animal diversity. Those have been identified by thorough field observations. Suggestions have been put forwarded to preserve those species, at the same time to increase their numbers in future. Apart from that, a gender budget has been conducted to assess the level of gender bias in the college. For this, male-female ratio among the students, teaching and non-teaching staffs have been calculated. The scenario has been then analysed and necessary actions have been recommended to minimise the gender gap found in the college under study. In this way, the current study is an attempt to act locally to reach the aim of global environmental sustainability.
\end{abstract}

Keywords - Environmental accounting, sustainable development, biodiversity and gender accounting, gender bias.

\section{INTRODUCTION}

Human activities are directly or indirectly dependent on its surrounding environment. Every possible matter that is used by human civilization is a gift from the nature. So, it is the responsibility of every people to understand the importance of the environment and preserve it for the future to come. Though such discussions are very frequent at global level, but the needed actions at local level are very few. The present study is an attempt in this regard. Here, apart from the physical environment, the cultural component of the environment has also dealt with. The physical and cultural components have been studied with the help of biodiversity and gender accounting respectively.

\section{CONCEPT OF ENVIRONMENTAL ACCOUNTING}

Environmental accounting is a broad concept that covers different types of evaluations, which helps environmental management system. Confederation of British Industry has defined environmental accounting as "the systematic examination of interactions between any business organisation and its surroundings" [1]. It helps to indentify different environmental problems, gap in planning and implementation, harmful anthropogenic practices for environment etc. Along with this, various action plans are recommended to achieve the goals of sustainable development. The term environmental sustainability refers to a condition in which the demands placed to the environment can be met without reducing its capacity to allow all people to live well, now and in future. In this way, environmental accounting is a tool to achieve the goals and objectives of sustainable future.

\section{OBJECTIVES}

Major objectives of the present study are:

- to identify the present nature of biodiversity in the college campus.

- to study the gender disparity among the students, teaching and non-teaching staffs in the college.

- to recommend some measures to increase the richness of biodiversity by participation of students and faculties of the college.

- to suggest measures for the betterment of infrastructures and social-environment of all women involved in the college.

IV.

STUDY AREA

Tivenidevi Bhalotia (TDB) college is one of the largest colleges in the district of Burdwan, as well as in West Bengal. It was established in the year of 1957. It has a ground area of 30 bigha, of which almost 36 percent is open space. Apart from three big college buildings, there are 39 teachers' quarters, 12 single room messes for the teachers, 43 nonteaching staff quarters, along with a boys' hostel with a capacity of 60 students. This college has an approved student capacity of 2680. Among them there are 713 and 1200 seats for honours and general courses respectively in arts departments, whereas 429 and 302 seats for honours and general courses in science departments respectively. It should be mentioned, the department of Urdu language has student strength of 36 in post graduate level along with its apart from its under graduate students. This college has 68 approved teaching posts, including librarian and 20 part time teachers. In a whole, there are 88 teaching and 51 non teaching staffs. Apart from these, there is a bank counter within the college campus that generates numerous public interactions in the area under study. 


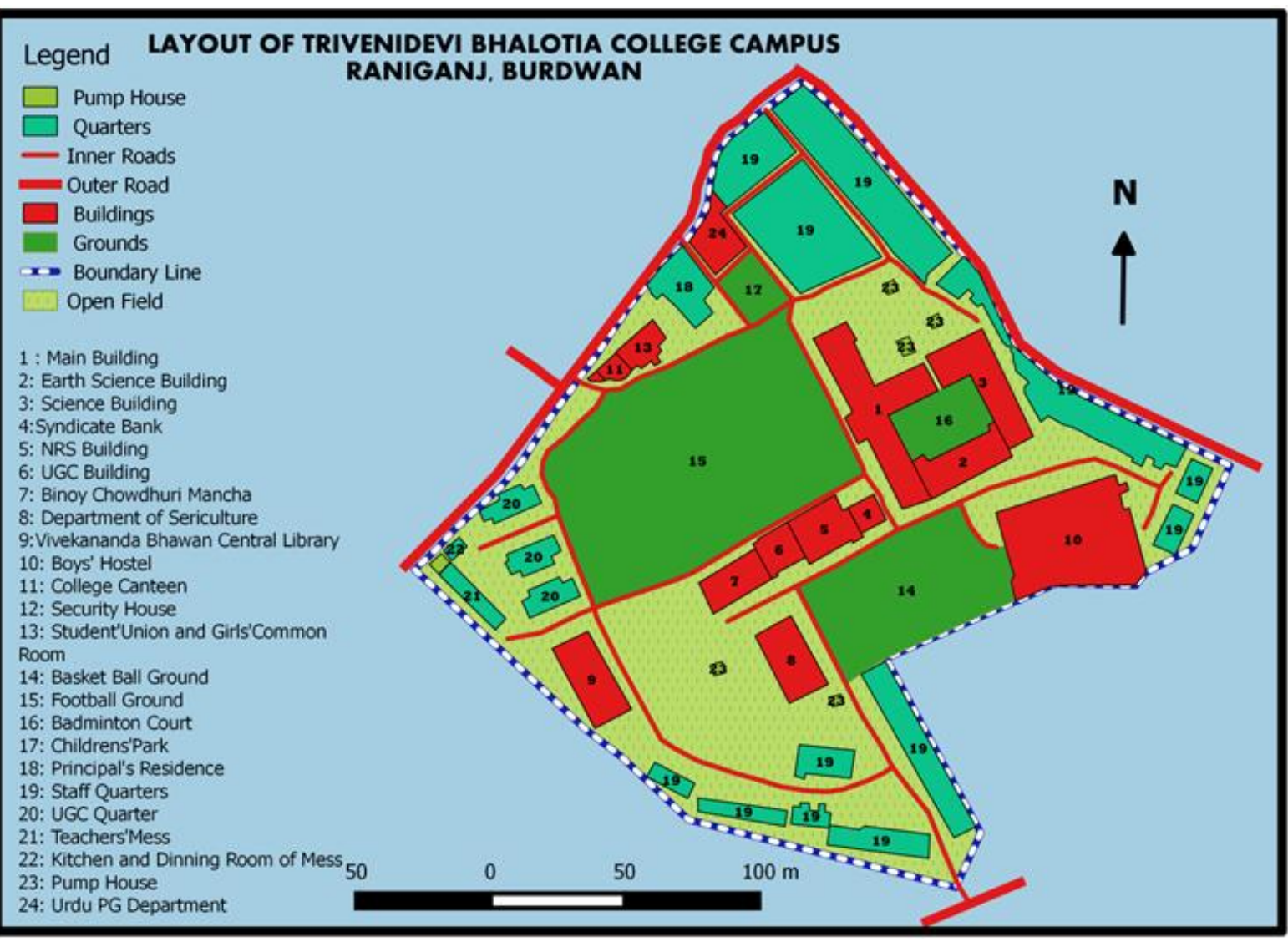

Figure 1

Source: Primary Data

Hence, TDB college campus, the area under study is a place of human interaction in large number and it is a big challenge to the authority to keep its environment clean and green. That is why; the college compound has been selected as a study area.

\section{METHODOLOGY}

In this study a thorough inspection of environmental components has been done to meet the criterion of environmental accounting. The study consists of three stages, i) pre-accounting activities, ii) onsite-accounting activities and iii) postaccounting activities. The process has been represented through the following chart.

To cover both the physical and cultural components of the environment of the study area, the discussion has been divided into two parts. A biodiversity accounting has been done for a proper inspection of the natural environment and a gender accounting has been conducted to explore the level of gender disparity in the study area.

\section{TYPES OF ENVIRONMIENTAL ACCOUNTINGS}

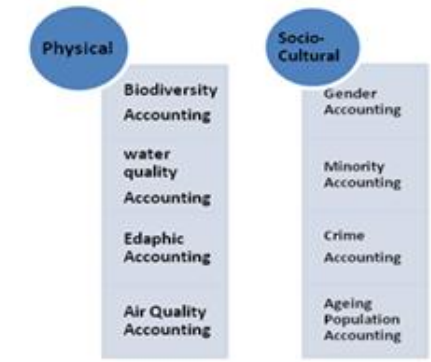

Figure 2 Source: compiled by the author

\section{STEPS OF ENVIRONMIENTAL ACCOUNTING}

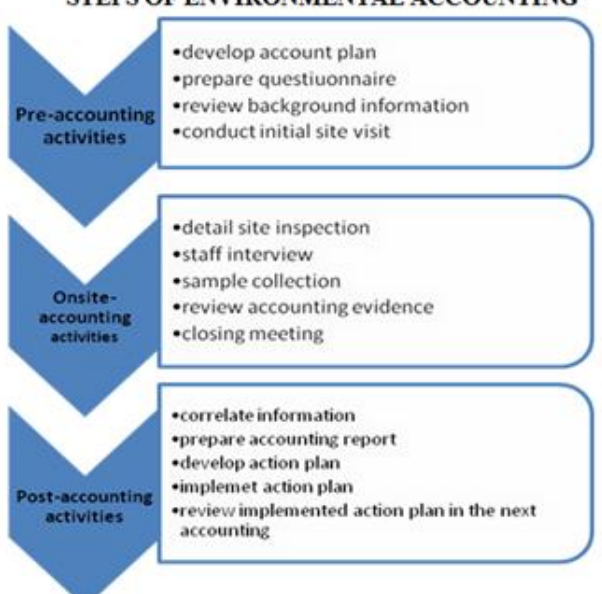

Figure 3 Source: compiled by the author

For the biodiversity accounting, all the plant and animal species found in the college campus has been identified by field survey, which gives an idea of species diversity for the study area. 
For the gender accounting, data has been collected from the college authority regarding gender wise numbers of students, teachers and non-teaching staffs of different categories.

Then those have been represented and analysed with proper cartographic techniques as required. A lay out map of the college campus, i.e. the study area has been prepared by the author. That helps to develop an idea over the study area.

\section{THE BIODIVERSITY ACCOUNTING}

Biodiversity accounting helps to assess the biodiversity of any area. It is an attempt to identify the value of open space in the study area as spaces for wildlife. This study focuses on surveying the college campus to assess the diversity of flora and fauna found there. This gives idea about the variety of living things in the college coexisting with the academic activities. These include trees, shrubs, smaller plants and grasses, as well as numerous birds, mammals and small invertebrates such as spiders and insects [2].

The table number 1 and 2 shows the variety of plant species found in the college campus. The vast open area of the college compound supports the growth of rich species diversity. It is very rare that an educational institution possesses such treasure of nature.

\section{ACTION PLAN FOR BIODIVERSITY MANAGEMENT}

As a part of biodiversity accounting, an action plan has been prepared to preserve as well as increase the biodiversity of the area under study. These have been mentioned here.

1.1.1 Plant Adaptation Programme: The college has a massive human resource, consisting of 20 undergraduate and a post graduate departments. Under the scheme of 'plant adaptation programme' it is recommended that, each department will plant a sapling every year and all the teaching, non-teaching and students of the respective department will be responsible its sustainability. In this way, not only plantation of new trees, proper care will be taken to preserve the biodiversity.

Table 1: List of plant species recorded in the TDB College Campus

\begin{tabular}{|c|c|c|c|}
\hline Sl. No. & Flora & Scientific Name & Number \\
\hline 1 & Mango & Mangifera Indica L. & 4 \\
\hline 2 & Custard Apple & Anona Retriculata L. & 2 \\
\hline 3 & Wood Apple & Aegle Marmelos L. & 2 \\
\hline 4 & Margosa & Azadirechta Indica A. Juss & 4 \\
\hline 5 & Fig tree & Ficus Rumphi Blume & 1 \\
\hline 6 & Kadam & Neolamarekia Cadomba Roxb & 2 \\
\hline 7 & Banyan & Flcus Bengalensis L. & 2 \\
\hline 8 & Peepul & Ficus Religiosa L. & 4 \\
\hline 9 & Black Berry & Syzyzium Cumini L. & 2 \\
\hline 10 & Tamarind & Tamarindus Indica L. & 1 \\
\hline 11 & Nishindra & Vitex Nigundo L. & 2 \\
\hline 12 & Chatim & Alstnia Scolaris R. B. R. & 10 \\
\hline 13 & Deoder & Polyalthia Longifolia L. & 12 \\
\hline 14 & Gulmohor & Denonix Regia L. & 1 \\
\hline 15 & Krishnachura & Caesalpina Pulchirimal & 7 \\
\hline 16 & Banana & Musa Paradisical L. & 5 \\
\hline 17 & Gule & Albizia Lebbex L. & 4 \\
\hline 18 & Timber & Dalbergia Sisoo Roxb & 3 \\
\hline 19 & Silk Cotton & Bombox Caba L. & 5 \\
\hline 20 & Betel - Nut & Areca Catecu L. & 2 \\
\hline 21 & Kanchan & Bauhinia Acuminita L. & 3 \\
\hline 22 & Jack Fruit & Artrocapus Hetelophyllusl & 10 \\
\hline 23 & Kamini & Murraya Paniculata L. & 2 \\
\hline 24 & Jarul & Lagerstroemia Speciosa L. & 1 \\
\hline 25 & Cocont & Cocos Nucifera L. & 2 \\
\hline 26 & Segun & Tectona Grandis L. & 5 \\
\hline 27 & Sajina & Moringa Oleifera Lamk & 2 \\
\hline 28 & Tunt & Morus Alba L. & 5 \\
\hline 29 & Sonajhuri & Acasia Auriculoformis L. & 2 \\
\hline 30 & Eucalyptus & Eucalyptus Globulus L. & 4 \\
\hline 31 & Papaya & Corica Papaya L. & 3 \\
\hline 32 & Mehagini & Swietenia Mehagini L. & 4 \\
\hline 33 & Kolke & Thevetia Peruviana L. & 2 \\
\hline 34 & Jaba & Hibiscus Rosa - sinesis L. & 4 \\
\hline 35 & Tagar & Tabernaemontena Divericata & 4 \\
\hline 36 & Casuarina & Casuarina Equsetifolia L. & 1 \\
\hline
\end{tabular}




\section{Table 2: List of Animal Species recorded in TDB College Campus}

\begin{tabular}{lll}
\hline Sl. No. & Fauna & Scientific Name \\
1 & Pigeon & Columbia Liria \\
2 & Duck & Anas Platynhyncha \\
3 & Honey Bee & Apis Mellifera \\
4 & Dog & Connis Familiaris \\
5 & Cat & Felis Catus \\
6 & Ant & Hymenopetrous \\
7 & Bat & Chiroptera \\
8 & Mouse & Radentia Muridae \\
9 & Dove & Columbidae Colombiformes \\
10 & Duck & Analidae Anseriformes \\
11 & Owl & Nocturnalis Strigiforms \\
12 & Sparrow & Ploceidae Passer \\
13 & Crow & Corrous Carone \\
14 & Spider Monkey & Arboreal Ateles \\
15 & Frog & Anura Ranidal \\
16 & Squirrel & Radentia Sciurus \\
17 & Cuckoo & Cuculidae cuculiformes \\
18 & House Mouse & Mus Musculus \\
\hline
\end{tabular}

1.1.2 Solar Energy Scheme: As per the 2013-14 financial accounting, the college paid rupees 52,000 per month for its electricity bills. The rooftop area of main buildings of college is approximately 10,000 sq. ft. If solar panels are installed to provide power in college buildings, it will cost about 62 lakhs initially, but it will reduce the ever increasing recurring cost of conventional electricity bills. Not only that, it will show the way to a sustainable use of energy resource.

1.1.3 Habitat Preservation: Any human activity that would create a threat to the habitat of flora or fauna in the study area should be checked strictly. Construction of new buildings, concretisation of earthen roads or open spaces etc. should not be done with the cost of destruction of natural habitats of different species.

\section{THE GENDER ACCOUNTING}

'Gender Accounting' is an attempt to enquire whether the college under study has a gender disparity [3]. To have a clear idea about the gender gap in the college, gender wise data have been collected from the college authority regarding enrolled students, recruited teaching and non-teaching staff of the college (Fig. 4). There is a clear imbalance or gender disparity among the teaching and non-teaching staffs of the college.

Among the associate and assistant professors 76 and 61 percent are male respectively. There is only one male librarian in the college. 67 percent of the general laboratory instructors are male whereas 92 percent non-teaching staffs are male. That exhibits an overall male biasness among different faculties of the college. The notable thing is that, participation of female staff is higher among the part time teachers (PTT), which are not permanent jobs. So, not only poor participation in various departments and offices works, insecurity of job is also a major problem for the women employees.

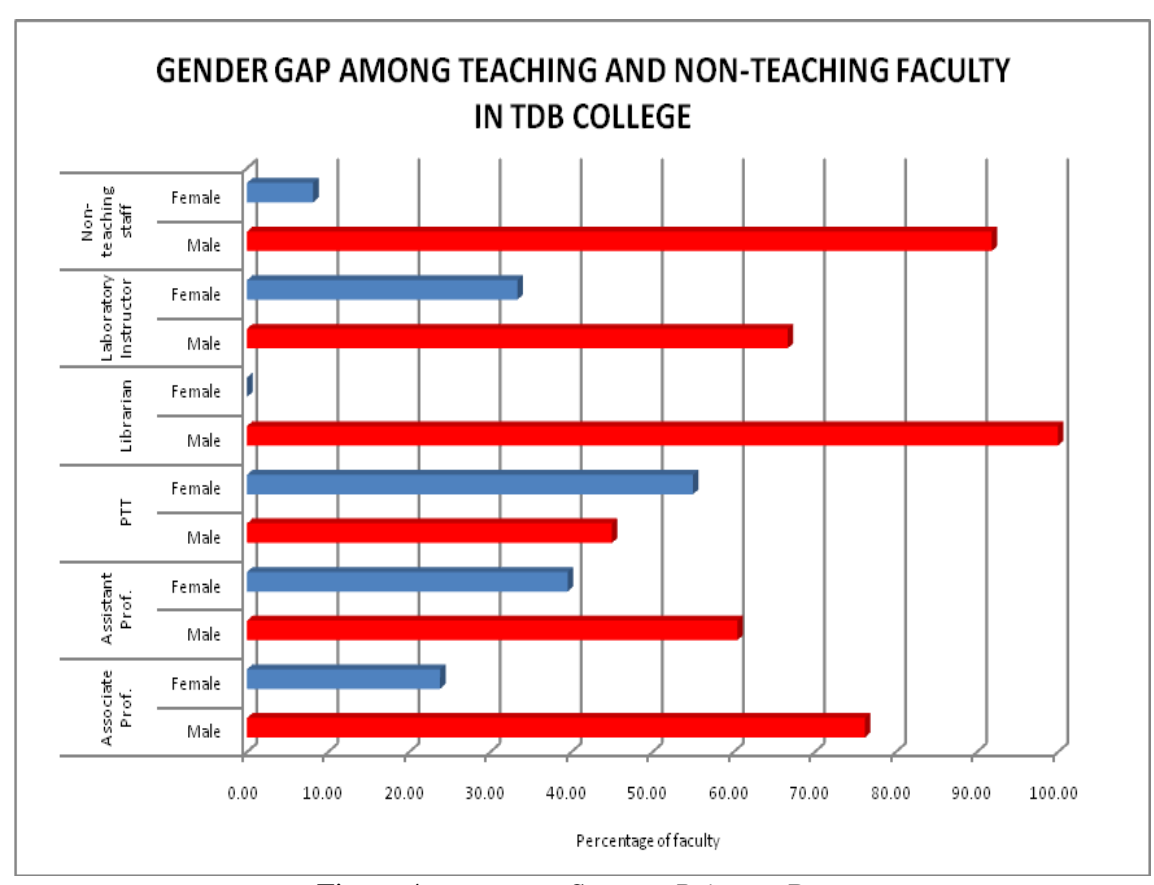

Figure 4

Source: Primary Data 
Women are lacking behind their male counterparts in terms of gaining higher education also. There are ten associate professors in the college having Ph. D. Degree, of them six are male. Ten assistant professors have Ph. D. Degree, where as only six female assistant professors have that degree. None of the female associate professors have a M.Phil degree, whereas three male associate professors have that degree. Among the assistant professors, three male and only one female have M.Phil degrees (Fig. 5). So, it can be said, male teaching staffs of this college possess more degrees in higher education than the females.

Gender disparity has also been found among the students of the college. For its analysis, student enrolment from 2011-12 to 2014-15 has been considered (Fig. 6). It is seen, that in almost all cases number of male students exceeds the number of girl students. Only in 'other' category the gender gap is relatively low, but in all cases like general, scheduled cast, scheduled tribe and other backward classes male students are dominant. In the recent years this gender gap in relatively high than the previous years. As it is seen in case of 2014-2015 academic session, there were 1300 boys, whereas only 723 girls were admitted. This disparity is also present in the category wise distribution of male and female students of the college. Especially, in case of Scheduled Cast and Scheduled Tribe categories, numbers of girl students are only 27 and 4 respectively, whereas numbers of male students in the same categories are 196 and 34 respectively. Unavailability of Girls' hostel facility in the college perhaps is the main reason for less amount of girls' enrolment. Otherwise there is no report any incidents that goes against of the girl students, like sexual harassment, ragging etc.
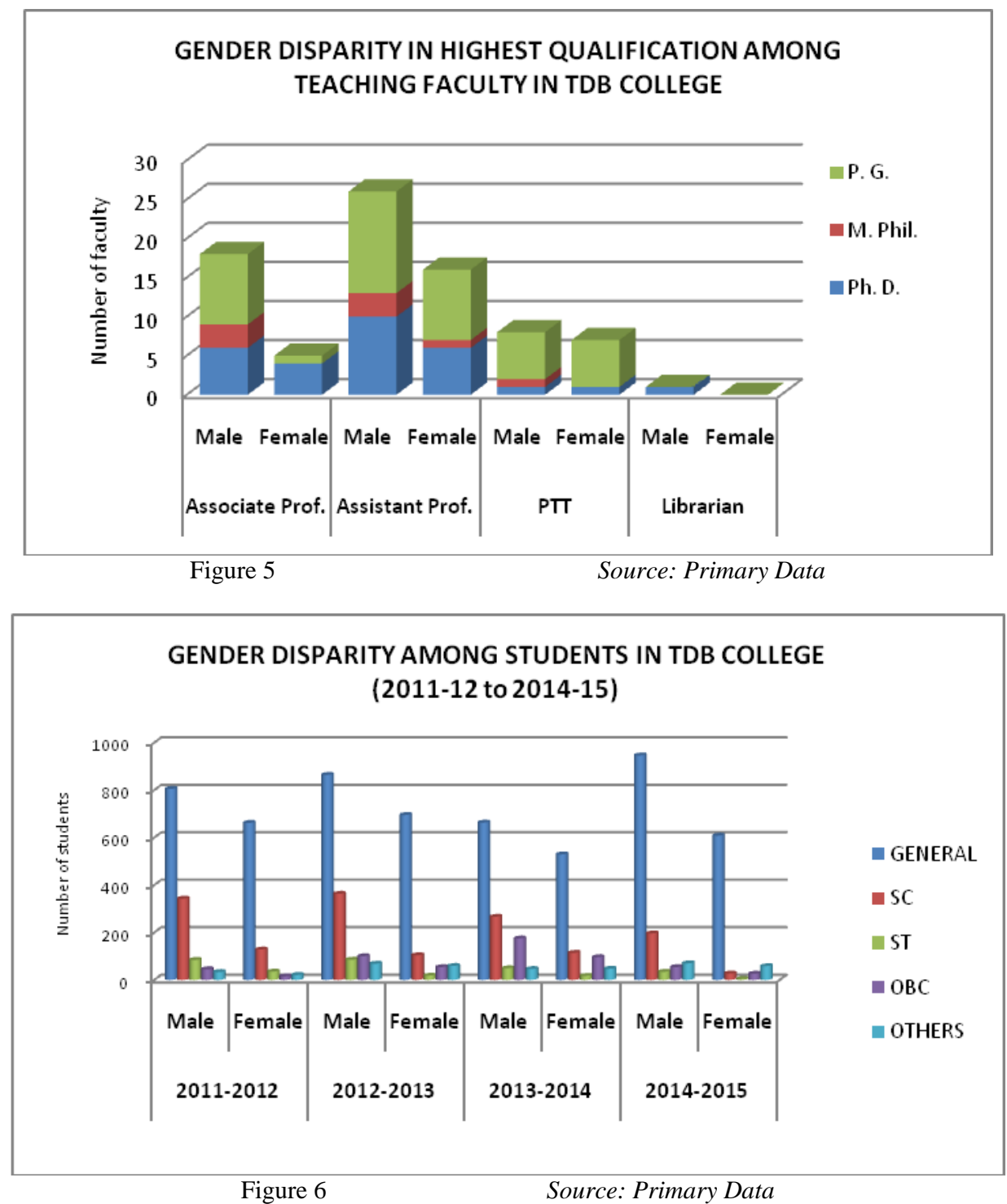
very alarming.

As far as the socio-cultural environment of the college is concerned, such disparity in male-female distribution is

\subsection{Action Plans for Gender Development}

It is clear from the above discussion that, existence of gender imbalance in TDB College is quite prominent. Hence, some steps may be taken to reduce the disparity or to prevent any unwanted incident that can go against of the ladies in this college. 
1.1.4 Internal Complaints Committee: This committee should be more active in future to support the women of the college in any crisis. It may organise workshop on Women and Law, Women's empowerment, Women and Human Rights etc.

1.1.5 Establishment of Girls' Hostel: Students come from distance places to get admission in this college. But absence of secured shelter reduces the admission of girls. So, hostel facility for girls might improve the girls' enrolment in future.

1.1.6 Women's representative in Governing Body: No women representation is found in the Governing Body (G.B.) of the college. The college authority may consider appointing more women in the G. B. The college should be intended to ensure that the inclusion of more women in decision-making be embedded in college practices.

1.1.7 Girl's representation in students' union: TDB College never had a girl General Secretary in their students' union. So, participation of girl students in students' union certainly help to reduce gender discrimination in the college.

1.1.8 Increase in female non-teaching staff: The college authority should consider to increase female staff in the Nonteaching faculty.

1.1.9 Development of infrastructural facilities for ladies in college: Some infrastructural facilities may be developed to facilitate women. That might reduce the gender disparity in college. Improved more hygienic washroom, separate cycle or two wheeler stand, separate reading space/room in library, exclusive counter in the office etc. for girls may be planned for this purpose.

\section{CONCLUSION}

The college under study has enormous potentiality in its natural environment and human resource. It is the responsibility of the college authority to formulate such policies that would help to maintain a balance between its physical and socio-economic environment. To achieve this, environmental accounting is a tool that should be used properly. As its methodology explains, proper examination of the environmental components, followed by proposed action plans and regular investigation regarding the execution of the proposals certainly help the institution to achieve the sustainability in long run. There is lots of scope to improve the condition of the college as far as its environmental condition is concerned. By initiating such activity of saving its environment at local level, environmental sustainability at global level may be achieved.

\section{REFERENCES}

[1]. Stephen Asbury, Health And Safety, EnVIRonment And Quality Audits: A RISK-BASED APProach (Routledge, TAYLOR AND FRANCIS GROUP, 2014)

[2]. Oecd, United Nations, European Union, The World Bank, Food And Agriculture Organization Of The United Nations: System Of Environmental Economic Accounting 2012 Experimental Ecosystems (United Nations, 2014)

[3]. Ahmed Riahi Belkaoui, The Cultural Shaping Of Accounting (Quorum Books, London, 1995. 